\title{
Distance Learning Degrees: Possibility of Evasion, Styles and Learning Strategies
}

\author{
Raíssa Bárbara Nunes Moraes Andrade ${ }^{1}$ (iD https://orcid.org/0000-0002-4573-5372 \\ Thaís Zerbini ${ }^{1}$ (iD https://orcid.org/0000-0001-6799-3658
}

\begin{abstract}
Distance Learning (DL) has been shown to be adequate to the current field of Training, Development and Education (TD\&E), which constantly undergoes transformations resulting from technological innovations. Students' characteristics is one of the factors responsible for abandoning DL programs. This study aimed to relate the possibility of evasion of a DL course and the variables belonging to the student's characteristics (Learning Strategies and Styles). A total of 135 students enrolled in a distance learning degree responded virtually to the instruments of Learning Strategies and Styles. The results showed that most participants who would not abandon the course used the Behavioral and Self-Regulated Learning Strategies and presented the Learning Style related to the Study Environment. The data obtained contribute to future planning of TD\&E programs, which should consider the clientele's characteristics.
\end{abstract}

Keywords: distance education, student's characteristics, evasion

\section{Ensino Superior a Distância: Possibilidade de Evasão, Estilos e Estratégias de Aprendizagem}

\begin{abstract}
Resumo: A Educação a Distância (EAD) tem se mostrado adequado ao atual campo de Treinamento, Desenvolvimento e Educação (TD\&E), que passa constantemente por transformações decorrentes de inovações tecnológicas. Características dos estudantes é um dos fatores responsáveis pelo abandono de programas de EAD. O objetivo deste estudo foi relacionar a possibilidade de evasão de um curso em EAD e as variáveis pertencentes às características do estudante (Estratégias e Estilos de Aprendizagem). Responderam, virtualmente, aos instrumentos de Estilos e Estratégias de Aprendizagem, 135 alunos matriculados em um curso superior a distância. Os resultados demonstraram que a maioria dos participantes que não abandonariam o curso utilizam as Estratégias de Aprendizagem Autorregulatórias e Comportamentais e apresentam o Estilo de Aprendizagem relacionado ao Ambiente de Estudo. Os dados obtidos contribuem para futuros planejamentos de programas de TD\&E, que devem levar em consideração as características da clientela.
\end{abstract}

Palavras-chave: educação a distância, características do estudante, evasão

\section{Enseñanza Superior a Distancia: Posibilidad de Deserción Escolar, Estilos y Estrategias de Aprendizaje}

\begin{abstract}
Resumen: La Educación a Distancia (EAD) se ha demostrado apropiada para el campo actual de Capacitación, Desarrollo y Educación (CD\&E), que está experimentando constantemente transformaciones resultantes de las innovaciones tecnológicas. Una de las razones para el abandono de los programas de EAD son las características de los estudiantes. El presente estudio tuvo como objetivo relacionar la posibilidad de deserción de un curso EAD con las variables que pertenecen a las características del estudiante (Estrategias y Estilos de Aprendizaje). Han respondido virtualmente a los instrumentos de Estilos y Estrategias de Aprendizaje 135 estudiantes que estaban inscriptos en un curso de educación superior a distancia. Los resultados revelaron que la mayoría de los participantes que no abandonaron el curso usan Estrategias de Aprendizaje Autorreguladoras y Conductuales y presentan el Estilo de Aprendizaje relacionado con el Ambiente de Estudio. Los datos obtenidos contribuyen a futuras planificaciones de programas de CD\&E, que deben tener en cuenta las características de la clientela.
\end{abstract}

Palabras clave: educación a distancia, características del estudiante, deserción

${ }^{1}$ Universidade de São Paulo, Ribeirão Preto - SP, Brazil

Support: This article derived from the first author's master's dissertation under supervision of the second, defended in 2016, in the Graduate Program in Psychology of the Faculdade de Filosofia, Ciências e Letras de Ribeirão Preto - Universidade de São Paulo. This study was funded by São Paulo Research Foundation (FAPESP) (process 2014/18466-9).

Correspondence address: Raíssa Bárbara Nunes Moraes Andrade. Universidade de São Paulo. FFCLRP-Psicologia, Avenida Bandeirantes, 3900, Ribeirão Preto-SP, Brazil. CEP 14040-900E-mail: raissa.nmoraes@gmail.com
To an increasing extent, actions developed in the field of Training, Development and Education (TD\&E) are highlighted in terms of importance and necessity, since the new contexts of teaching and work require initiatives that are capable of remediating gaps of competencies and that promote their constant update, aiming at good academic and professional performance (Umekawa \& Zerbini, 2015). Regarding the evaluation of educational actions - the focus of this study - the literature has been 
concentrating its efforts on refining the methodologies and skillful procedures to analyze educational actions to ensure the transfer and application of acquired skills (Salas \& Cannon-Bowers, 2001). The work by Iglesias and Salgado (2012) demonstrated that when correctly delineated and implemented, DL can produce results analogous to classroom education. However, the authors state that studies evaluating the effectiveness of instructional actions are still scarce and present incongruences regarding the intended objectives.

The various definitions of the term Distance Learning (DL) (Vargas \& Abbad, 2006) have some points in common, presenting a minimum consent in relation to DL as a teaching modality, whose activities occur mostly without requiring the presence of professors and apprentices in the same time and space. According to Almeida, Abbad, Meneses, \& Zerbini (2013), the elementary characteristics of DL could be designated as: (a) physical distance between professor and student; (b) learning process administered by the student and not by the tutor, who plays an auxiliary and facilitator role in this context; (c) professor-student relationship sustained by various technological media (television, internet, intranet, radio, CD-ROM, and printed material are examples of such resources); and (d) the malleability of content to be learned (the learner structures his/her own learning, according to his/her educational needs).

The expansion and improvement of the information and communication technology (ICT) area has greatly contributed to the differentiated resources and instructional strategies employed in the teaching and learning processes. Acting as a strategic device in this new instructional reality, the DL - by resorting to advanced digital media and interaction tools - has enabled an increasing contingent of individuals not only to have access to content and information, but to establish contact despite possible physical distance (Bjork, Dunlosky \& Kornell, 2013; Iglesias \& Salgado, 2012; Raymond et al, 2014).

DL faces serious challenges involving factors that interfere with the efficiency and employability of such instructional efforts. One of the most relevant problems in the field of Distance Education and Training is the scarce production and systematization of knowledge about the causes that interfere with the advancement and completion of formal and distance teaching-learning actions (Bell, Tannenbaum, Ford, Noe, \& Kraiger, 2017; Umekawa \& Zerbini, 2015).

Despite the growing interest in distance courses and the recognition of their benefits and advantages, there are still serious gaps in the production and systematization of this area of knowledge, which thus require analyses and discussions covering distance learning actions (Bell et al., 2017; Martins \& Zerbini, 2014; Umekawa \& Zerbini, 2015). Regarding the educational sphere and considering the increasing insertion and importance of DL in this environment, Martins and Zerbini (2014) affirm that there is a need for investigations stating the effectiveness and applicability of this teaching modality through empirical studies with an inferential approach which present a theme of social and academic relevance, besides bringing relevant contributions to the planning, implementation and evaluation of this type of educational action. Primarily, to investigate what lead students not to complete distance learning courses can provide important subsidies for educational institutions that would engage in preventive work to reduce evasion levels (Almeida, Abbad, Meneses, \& Zerbini, 2013).

According to the Ministry of Education (MEC), the term evasion in the Brazilian context is the definitive withdrawal from a course of origin without conclusion, or the difference between first-year enrolled students and graduates, after a complete generation. When referring to a complete generation, the Ministry assumes the idea that the time between admission and conclusion is defined as the maximum period of completion of the course (Fritsch, Rocha, \& Vitelli, 2015). Baggi and Lopes (2011) state that the theme of school evasion in higher education is a complex phenomenon and, therefore, cannot be analyzed without a broader historical context, reflecting the reality of previous educational levels, influencing several ways of abandoning a higher course.

For Simpson (2013), the issue of students' withdrawal and retention is regarded as the main element for the success of DL. The author indicates that distance education has presented low levels of completion, corresponding to $25 \%$, or less, of those obtained by classroom education. Still, the gaps related to the investigation of evasion in educational contexts of learning distance are still large and worrying, making it strictly necessary to conduct more systematic studies on such phenomenon.

Considering that the studies on the DL field and, in particular, those investigating the reasons for student evasion are still scarce (Umekawa \& Zerbini, 2015), it becomes important to carry out studies that include such a variable, relating it to the various elements that surround learning distance courses). Thus, the present study aims to contribute to the TD\&E field by providing elements that can help understanding the causes that lead students to evade distance courses.

Umekawa and Zerbini (2015) show in their study that the factors referring to the target audience's characteristics of distance educational actions, besides being extremely relevant for the planning of courses in such modality, are also seen as related to evasion or persistence in DL. The authors verified a limited production of studies covering a systematic investigation of the effectiveness of distance educational actions. Thus, it was acknowledged the urgent need to refine the modality in relation to tutors' development, adaptation of the courses to the students' study environment, the appropriate use of the new tools available, the Learning Styles and Strategies and the apprentice's study habits, elements that are possibly related to the high evasion rates recorded and that hinder the returns to high investments in the implementation of this teaching modality.

Considering the motifs that lead the student not to conclude a DL program, the literature indicates reasons arising from the students' characteristics, the constraints inherent to the participant's study contexts and the design and execution of the course (Iglesias \& Salgado, 2012). Our study will investigate the aspects related to the target audience's characteristics (Learning Strategies and Styles).

Learning Strategies are procedures (cognitive and behavioral skills) used by individuals during learning activities to ensure the success of all stages of the process. These are procedures focused solely on learning activities. The strategies can be modified by training in order to increase the learning effectiveness in a specific activity or environment (Warr \& 
Allan, 1998). They can be understood as systematic actions undertaken by apprentices trying to fulfill certain tasks and achieve established goals. Offering subsidies to the processing of new knowledge, the Learning Strategies are positively related to a successful learning, according to studies of the organizational psychology or the educational field that focus on the student's characteristics (Oliveira, Boruchovitch, \& Santos, 2009).

The analysis and understanding of Learning Strategies can be of great value to improve the instructional planning of distance actions, since they favor the recognition of the individual learning processes used and the more appropriate instructional procedures for each agent involved (Martins \& Zerbini, 2014). The brief summary of Umekawa and Zerbini (2015) on works dedicated to the variable Learning Strategies reveals the concern to understand the skills employed by students in order to study and learn in diversified educational situations (Oliveira et al., 2009). Among the studies surveyed, a concern was identified regarding the promotion of metacognitive Learning Strategies and related to the management of time - considered very relevant to the selfregulation processes of knowledge and time, so present in virtual learning environments (VLE). Finally, as Beluce and Oliveira (2012), the field of scientific productions focused on the study of Learning Strategies in online teaching contexts has witnessed satisfactory advances, however it is necessary to recognize that such progress is not enough in view of the seriousness of the theme to education, in-person and distance. Thus, it is indispensable to develop studies that not only cover the aspects already considered, but provide new contributions to the study of this theme.

The findings of the study conducted by Martins and Zerbini (2014) point to the relationship between Learning Strategies and several other variables, such as motivation to study, content acquisition and retention, self-confidence and even individual variables (age, sex, years of schooling). In this sense, the Learning Strategies influence the teaching process in several aspects. However, there is a lack of studies relating Learning Strategies with school evasion, a fact that has already been discussed by Umekawa and Zerbini (2015) as a fundamental investigation.

Another clientele's characteristic considered important in deepening studies about evasion in DL actions are the Learning Styles (Umekawa \& Zerbini, 2015). There are several definitions and theoretical approaches related to Learning Styles, which have been studied by several areas of knowledge, such as Psychology, Education, Administration and Engineering (Brant, 2013). For Vermunt (1998), the Learning Styles are a coherent set of learning activities that individuals frequently use, according to the individual orientation and conceptions of learning. This author presented a theoretical model of Learning Styles - the Integrated Model of Student Learning - whose approach integrates a purely cognitive learning approach with the constructionist approach. It consists of four hypothetical learning dimensions: (a) cognitive processing strategies; (b) metacognitive regulation strategies; (c) mental models of learning; and (d) learning orientations.

Berings, Poell and Simons (2005) define Learning Styles as a tendency to use a certain combination of learning activities that derives from a combination of perceived preferences and capabilities. This theoretical model was developed specifically for the study of Learning Styles in a work context and received the name of Expanded Organismic Interactional Model of OnThe-Job Learning Behavior. According to it, Learning Styles are a tendency to use a particular combination of implicit and explicit activities (linked to individual and environmental factors, respectively) that a person can and enjoys engaging. Such learning activities, named mental or exposed, performed individually (intrapersonal) or with other people (interpersonal), define the Learning Styles dimensions (Brant, 2013).

Warr and Allan (1998) define Learning Styles as the student's preferences regarding contextual aspects and ways of studying. It covers the individuals' preference for certain study behaviors and aspects of the context in which it occurs. These are preferences focused on the context and learning activities, such as: noise level and ambient temperature when studying, preference for time of study, study form (individual, group). In this study, after an in-depth review of the literature followed by the construction and verification of evidence on validation of the Learning Styles instrument, the construct was defined as the students' preferences related to the context and study environment (light, noise, etc.), the way their learning is regulated (guidance of professors/ tutors in relation to the way of studying) and their interpersonal interaction (studying, doing activities and exchanging information with colleagues in the course).

Brant (2013) states that there are some foreign studies highlighting the influence of Learning Styles on final results of distance training. However, the analysis of the Brazilian scientific production in Learning Styles shows a strong predominance of studies in the educational area. Studies focused on the work context and Higher Education Institutes (HEI) are rare and most of them present inconsistency in the description of the method and in the presentation of results.

Warr and Allan (1998) attribute the same importance to the study of Learning Styles and Strategies, since information on individual preferences (Styles) can be useful to adapt the procedures used in the instructional event. Regarding evasion in DL, Umekawa and Zerbini (2015) indicate that empirical studies on this subject are still little extensive, so that it is justifiable to conduct investigations that propose to evaluate the elements related to the occurrence of evasion. For the authors, there is a clear need to develop new studies that not only cover the understanding of variables related to evasion in DL, but that propose theoretical models to evaluate this teaching modality. Given this context, this study aimed to identify the relationship between the evasion possibility of a DL higher course and the variables belonging to the clientele's characteristics (Learning Strategies and Learning Styles).

\section{Method}

\section{Participants}

A partnership with the Universidade de São Paulo was established - responsible for offering the distance course called "Teaching Degree in Sciences" - for the execution of this study. The "Teaching Degree in Sciences" - a semi-distance learning course - was taught by USP to satisfy a demand for improvement in São Paulo's Elementary and Middle Schools. This course is 
included in the program Universidade Virtual do Estado de São Paulo (UNIVESP - São Paulo Virtual University). The course is intended for the preparation of individuals that want to become apt to teach in Elementary School or Basic Education.

According to the course website (www.licenciaturaciencias. usp.br),360 annual vacancies are available every year and distributed across the 7 centers. The Ribeirão Preto (SP) center has approximately 205 vacancies, considering the four years of the course. Information on evasion was not available. Therefore, the number of enrollees in the course cannot be accurately affirmed.

The inclusion criterion for participation in the study was to be enrolled in any module of the course and to agree with the Informed Consent Form. Exclusion criteria were not being enrolled or have already completed the course. The sample consisted of 135 respondents. Regarding 205 vacancies, the rate of return was $65.8 \%$, which is considered a great index, especially in the context of data collection at a distance, which usually presents low rates of return (Umekawa \& Zerbini, 2015).
To study two homogeneous groups, as required in a T-Test, a random sample of 44 participants from the group who would not abandon the course (total of 91 participants) was selected. The sample size for students who would abandon the course was also of 44 students. Thus, two groups of 44 participants were set.

Most participants were between 40 and 49 years $(30.4 \%)$, with an average of 38 years of age $(\mathrm{SD}=10.16)$. Most students have Incomplete Higher Education (38.5\%). Among the professions presented by the participants, most of them indicate being a teacher (34.8). Finally, most of them stated having previous experience in internet use $(94.8 \%)$.

\section{Instruments}

Tables 1 and 2 present the data of the instruments applied in this study. These data were obtained after the instruments underwent exploratory analysis to verify evidence of their validity in a previous study (Moraes, 2016).

Table 1

Empirical structure of the Learning Strategies Scale

\begin{tabular}{|c|c|c|c|c|}
\hline \multirow{2}{*}{ Description of items } & \multicolumn{4}{|c|}{ Factorials loadings } \\
\hline & 1 & 2 & 3 & 4 \\
\hline 1. I remained calm when I had a difficulty & & 0.72 & & \\
\hline \multicolumn{5}{|l|}{ 2. When I felt anxious, I repeated to myself that everything would be okay at the end of the course. } \\
\hline 3. I remained calm with the possibility of having a yield below the expected. & & 0.78 & & \\
\hline 4. I remained calm before the mistakes I made when performing course activities. & & 0.60 & & \\
\hline 5. I tried harder when I realized I was losing focus. & 0.57 & & & \\
\hline 6. I forced myself to keep my attention in my studies when I felt uninterested. & 0.63 & & & \\
\hline 7. I tried harder when I realized I was losing interest on the subject. & 0.55 & & & \\
\hline 8. I reviewed the subject to verify how much I mastered the content. & 0.44 & & & \\
\hline 9. I tried harder to verify my understandinZZg of what was being taught. & 0.66 & & & \\
\hline 10. I looked for solving my doubts by consulting the course booklets. & 0.50 & & & \\
\hline 11. I sought to better understand the contents when studying them in the course booklets. & 0.51 & & & \\
\hline 12. I asked for help from the tutor to clarify my doubts about the content. & & & 0.43 & \\
\hline 13. I asked for help from colleagues in the forums to clarify my doubts. & & & 0.58 & \\
\hline 14. I exchanged messages with colleagues to clarify doubts about the course content. & & & 0.44 & \\
\hline 15. I sought other research sources, off the internet, related to the course to help me learn. & & & & -0.67 \\
\hline 16. I sought websites related to the course content to help me learn. & & & & -0.60 \\
\hline $\begin{array}{l}\text { 17. I tried to understand the content by applying it in practice, rather than devoting time reading or asking } \\
\text { someone for help. }\end{array}$ & & & 0.60 & \\
\hline \multicolumn{5}{|l|}{ 18. I reviewed the contents related to the exercises I made mistakes in. } \\
\hline 19. I learned content by mentalizing them repeatedly until I perceived that I understood them. & & & 0.80 & \\
\hline 20. I mentally repeated the course contents that I would like to learn. & & & 0.79 & \\
\hline 21. I took notes on the course contents. & 0.47 & & & \\
\hline \multicolumn{5}{|l|}{ 22. I made summaries of course contents. } \\
\hline 23. I read the course content several times as a learning method. & & & 0.52 & \\
\hline 24. I made schemes of the course content as a learning method. & & & 0.53 & \\
\hline 25. I reflected on the implications that the contents learned could have. & 0.81 & & & \\
\hline 27. I associated the course contents with my previous knowledge. & 0.40 & & & \\
\hline \multicolumn{5}{|l|}{ 28. I differentiated, when analyzing the course contents, the most important aspects from the least important. } \\
\hline 29. I identified daily situations in which I could apply the course contents. & 0.61 & & & \\
\hline $\mathrm{N}$ & 122 & 131 & 125 & 131 \\
\hline No. of items & 12 & 3 & 8 & 2 \\
\hline Alpha $(\alpha)$ & 0.90 & 0.81 & 0.83 & 0.80 \\
\hline
\end{tabular}


Table 2

Empirical structure of the Learning Styles Scale

\begin{tabular}{|c|c|c|c|}
\hline \multirow{2}{*}{ Description of items } & \multicolumn{3}{|c|}{ Factorials loadings } \\
\hline & 1 & 2 & 3 \\
\hline \multicolumn{4}{|l|}{ 4. To perform a parallel activity while studying, such as listening to music, watching TV, surfing the internet. } \\
\hline 10. To study together with other students. & & & 0.84 \\
\hline 12. To participate in the activities of virtual interaction (forums, chat) to discuss the contents with the other students. & & & 0.31 \\
\hline 13. To receive detailed instructions on the activities to be carried out in the course. & & 0.39 & \\
\hline 15. That professors/tutors explain clearly what is important to study to achieve the objectives proposed in the course. & & 0.48 & \\
\hline 20. To study in well-lit places. & 0.61 & & \\
\hline 21. To study in environments with little noise. & 0.86 & & \\
\hline \multicolumn{4}{|l|}{ 23. That learning assessments are performed to verify my domain of the content presented. } \\
\hline 25. To have printed reading material. & & 0.44 & \\
\hline 26. To be reminded about the deadlines of the course activities. & & 0.85 & \\
\hline $\mathbf{N}$ & 134 & 131 & 134 \\
\hline No. of items & 2 & 4 & 2 \\
\hline Alpha $(\alpha)$ & 0.76 & 0.63 & 0.40 \\
\hline
\end{tabular}

To investigate the possibility of evasion, a question inquiring about whether the student would abandon the course for some reason was included in the sociodemographic questionnaire used in this study. The participant could answer yes or no. The instrument "Learning Strategies Scale" by Martins and Zerbini (2014) was built for situations in Higher Education. Moraes (2016) verified the validity of the instrument (Table 1).

The Learning Styles instrument was built for the project that permeates this study (Moraes, 2016). For its construction, the author adopted a qualitative approach and conducted a literature review that assisted in the creation of the items, followed by a content analysis of the existing instruments. Subsequently, judges held the semantic validation of the instrument and selected 10 of the 26 initial items to remain in the instrument. Sixteen items were excluded due to the multiplicity of bibliographical references used in the construction of the instrument. After defining that the theoretical framework would be the Organizational and Work Psychology, several items were no longer considered a part of the Learning Styles construct. Finally, the Exploratory Factorial Analysis was applied to the instrument, which then remained with 8 of the 10 items initially analyzed. These 8 items were grouped into three factors, as described in Table 2.

Table 2 shows that the reliability indexes ranged from 0.40 to 0.90 , indicating that the scales presented internal consistency in their most (Pasquali, 2004). It is important to highlight that Moraes (2016) verified for the first and only time until then the evidence of validity of the Leaning Styles instrument, which justifies its factorial loads presenting lower values than the Learning Strategies instrument, which has been undergoing constant revisions and validations (Martins \& Zerbini, 2014; Moraes, 2016). The factorial loads, in turn, ranged from 0.31 to 0.86 , which indicates that the scales are valid and include representative items of the factor.

\section{Procedure}

Data collection. Data was collected at distance, through the internet. A free application which allowed the publication of the questionnaires online through a link was used. The completion of the questionnaires took about 20 minutes. The survey was available online for completion for 45 days. The answers were recorded in an online software with a spreadsheet format. The responses were subsequently imported into the SPSS version 21, a software program for data analysis. Data was not in public domain because only the responsible researcher could access it.

Data analysis. Omitted cases, extreme univariate and multivariate cases, multicollinearity, singularity and linearity were considered to calculate the T-test. The omissive data were treated by the pairwise method, since no variable presented more than $5 \%$ of the omitted cases. To identify the extreme univariate cases, all variables were transformed into $\mathrm{Z}$ scores and all responses whose standardized scores were equal to or greater than $3.29(\mathrm{p}<0.001$, two-tailed) were excluded. The extreme multivariable cases were identified from the Mahalanobis distance $(\alpha=0.001)$ and subsequently excluded. After the factorial scores of the instruments were obtained, they were submitted to a bivariate correlation, being considered for analysis the significant correlations, considering $\mathrm{p}<0.01$. Correlations greater than 0.30 were considered.

\section{Ethical Considerations}

The research project was submitted to the Research Ethics Committee of the Faculdade de Filosofia, Ciências e Letras de Ribeirão Preto of the Universidade de São Paulo. After approval (CAAE No. 44415715.5.0000.5407), the participating university was contacted and the coordinator of the Ribeirão Preto center was informed about the research objectives and the procedures that would be used. Upon authorization, the study could be conducted. For the participant to access the questionnaire and answer it, he/ she should first read and agree with the Informed Consent Form. 


\section{Results}

\section{Descriptive results regarding the possibility of evasion}

The last question of the sociodemographic questionnaire dealt with the possibility of students' evasion, with the question: "Would you abandon the course for a reason?". Table 3 details the results.

Table 3

Descriptive results on the possibility of evasion

\begin{tabular}{ccc}
$\begin{array}{c}\text { Would you abandon the } \\
\text { course for some reason? }\end{array}$ & Frequency & Valid percentage \\
\hline Yes & 44 & 32.6 \\
No & 91 & 67.4 \\
Total & 135 & 100.0 \\
\hline
\end{tabular}

\section{Results regarding the relationship of study variables}

To verify if the possibility of evasion relates to the variables Learning Styles and Learning strategies, tests of difference of averages (T-test) were performed. These tests aim to identify possible significant differences between the possibility of evasion and the factorial scores of the scales used to measure Learning Styles and Strategies. Therefore, this study could identify some characteristics of the student that would abandon the course for some reason.

To perform these analyses, the answer to the question related to the abandonment of the course for some reason was transformed into the variable-criterion of the model. The variables inserted separately in the model were the means of the participants' responses to the Learning Strategies and Learning Styles Scales.

As previously mentioned, to study two homogeneous groups, two samples of the same size were selected: one of the group that would not abandon the course and one of the group who would abandon it. Two groups of 44 participants were built.

The result of the difference test between means (T-test), considering $\mathrm{p}<0.05$, shows that the participant who would not abandon the course uses more frequently the Self-Regulatory Learning Strategies than the participant who would abandon the course for some reason. The group that would not abandon the course had a mean equal to $8.21(S D=1.26)$, whereas the group of students who would abandon the course had a mean equal to $7.58(S D=1.36)$, for a T-test of $2.13(\mathrm{gl}=77$; $p=0.036$ ). The group that would not abandon the course also uses more frequently the Behavioral Learning Strategies, presenting an average of $8.92(S D=1.24)$, while the group that would abandon the course presented a mean of 7.81 $(S D=2.73)$, for a T-Test value of $2.40(\mathrm{gl}=84 ; p=0.018)$.

In relation to Learning Styles, students who would not abandon the course value more the aspects of the environment in which they study, presenting a higher mean of Study Environment ( $\mathrm{M}=4.77 ; \mathrm{SD}=0.36)$ than students who would abandon the course $(\mathrm{M}=4.45 ; \mathrm{SD}=0.88)$. The $\mathrm{T}$-Test value in this case was $2.23(\mathrm{gl}=85 ; \mathrm{p}=0.028)$.

In short, the T-tests showed that the participant who would not abandon the course for some reason: (1) makes more use of Self-Regulatory Learning Strategies; (2) makes more use of Behavioral Learning Strategies; (3) values more the aspects of the Environment where he/she studies.

\section{Discussion}

The analysis performed with the T-test refers to the evasion and use of Learning Strategies and Styles. The use of Learning Strategies and Styles by students who would abandon the course was evaluated.

The importance of the study on the influence of the Learning Styles and Strategies on the evasion of distance courses has already been presented in the literature (Umekawa \& Zerbini, 2015). Thus, this study contributed to the completion of this aforementioned gap, since it showed that the SelfRegulatory Learning Strategies, Behavioral Learning Strategies and the aspects of the Study Environment directly influence the possibility of evasion in a distance course.

Due to the impossibility of measuring exactly the number of students who actually evaded the course - since this information could not be made available by the partner institution -, the sociodemographic questionnaire included a question that investigated whether, for some reason, the student would evade the course. This collection technique does not accurately guarantee the number of evaded students, demonstrating only the possibility of evasion. Further studies should include in this model the evasion itself.

This study presented the following research question: Are Learning Styles and Learning Strategies related to the possibility of students evading a course in the DL modality? This study showed that students who would not abandon the course for some reason have preferences related to the Study Environment (greater demand in relation to the luminosity of the place, noise level, etc.). In addition, these students use the Self-Regulatory Learning Strategies (force themselves to keep the attention in the studies, strive more when losing concentration, consults the booklet of the courses, can reflect on practical implications, relates the knowledge acquired with previously acquired knowledge, etc.) and the Behavioral Strategies (consult websites to assist in studies, consult other search sources outside the internet to help them learn, etc.). Thus, the results show that the students' Learning Styles and Strategies influence, in a way, the possibility of course evasion, and consequently its persistence.

The findings of this study aim to collaborate with previous studies (Martins \& Zerbini, 2014; Umekawa \& Zerbini, 2015) that evidenced the need for further investigation about the clientele's characteristics (Learning Styles and Strategies) and their relationship with evasion. They also corroborate Umekawa and Zerbini (2015) in the sense that a relationship was found between the target audience's characteristics of distance education actions and evasion or persistence in DL. 
The continuous improvement of distance courses collaborates for the modality to be recognized as an available educational alternative, with applicability attested through scientific studies. These studies can provide knowledge and discussions about the necessary elements so that the modality does not fall into discredit and is constantly subdue to prejudices and derogative comments about its quality and efficacy, providing subsidies to higher education institutions that often need specialized guidance for the implementation and monitoring of DL courses. Moreover, the evaluation and improvement of distance courses can result in the elaboration of more complex educational objectives, directly impacting on the design of teaching strategies and learning assessments compatible with them (Martins \& Zerbini, 2014). Thus, to better understand the students' characteristics, such as their Learning Styles and Strategies, can contribute to the improvement of the distance courses, which after being adaptable to each student, may present lower rates of evasion possibility, as described in this study. The consideration of the students' characteristics, as well as the adaptation to each individuality must be made during the design of these instructional events.

According to Martins and Zerbini (2014), the evaluation area higher education courses, specifically, distance undergraduate degrees, is very incipient and lacks systematic studies, which propose multivariate models of evaluation and use measuring instruments for courses in the DL modality. It should be considered that this is a field of knowledge still in the exploration phase, with few studies and instruments available in the literature. It is recommended that the scales used in this research are applied in different contexts of HEI and samples that study essentially the distance.

With a larger number of participants, one can measure how much the use of Learning Styles and Strategies influence the evasion in educational actions offered by distance through more robust statistical methods, such as Structural Equation Modeling (ESM). Regarding evasion, the methodology for data collection should be advanced to allow accurate measurement of the number of students that evaded the course.

The main limitations of this study are related to (1) not using more robust statistical methods, which could collaborate in the testing of prediction models; (2) impossibility of generalizing the results found in this study to other contexts and participants, since only one course of only one HEI was evaluated; (3) the sample that, although relatively large compared to the population, is still insufficient to perform other necessary analyses; (4) the methodologically-fragile question to measure evasion, because it questioned only whether the student would abandon the course for some reason, but did not measure whether or not she/he evaded.

The contributions of this study relate to the relationship between the possibility of evasion in DL higher courses and Learning Strategies and Learning Styles. Such contributions fill some gaps found in the literature review conducted for this study. Concomitantly, a further investigation on Learning Styles and Learning Strategies for students of DL courses was held. The need for such investigation is also widely cited in the literature (Martins \& Zerbini, 2014; Umekawa \& Zerbini, 2015). In practical matters, this study collaborates in the planning of future courses and trainings offered in the DL modality, which should take into account the participants' characteristics so that the evasion rates can be possibly minimized.

Given the results and discussions that have been promoted so far, future studies should assess: (1) the application of the measuring instruments used in this study in other contexts and samples, for example in organizations offering distance courses; (2) the measurement of the evasion variable in a more robust way, through the improvement of the data collection method.

\section{References}

Almeida, O. C. S., Abbad, G., Meneses, P. P. M., \& Zerbini, T. (2013). Evasão em cursos a distância: Fatores influenciadores [Dropout in distance education courses: Influencing factors]. Revista Brasileira de Orientação Profissional, 14(1), 19-33. Retrieved from http://pepsic. bvsalud.org/scielo.php?script=sci_arttext\&pid=S1679$33902013000100004 \& \operatorname{lng}=p t \& t \operatorname{lng}=p t$

Baggi, C. A. S., \& Lopes, D. A. (2011). Evasão e avaliação institucional no ensino superior: Uma discussão bibliográfica [Dropout rates and institutional evaluation in higher education: A bibliographical discussion]. Avaliação (Campinas), 16(2), 355-374. doi:10.1590/S1414-40772011000200007

Bell, B. S., Tannenbaum, S. I., Ford, J. K., Noe, R. A., \& Kraiger, K. (2017). 100 years of training and development research: What we know and where we should go. Journal of Applied Psychology, 102(3), 305-323. doi:10.1037/ap10000142

Beluce, A. C., \& Oliveira, K. L. (2012). As estratégias de ensino e de aprendizagem em condições de ensino online [Teaching and learning strategies in online learning conditions]. Hipertextus Revista Digital, 9, 1-16. Retrieved from http:// www.hipertextus.net/volume9/06-Hipertextus-Vol9-AndreaCarvalho-Beluce_\&_Katya-Luciane-de-Oliveira.pdf

Berings, M. G. M. C., Poell R. F., \& Simons, P. R. J. (2005). Conceptualizing on-the-job learning styles. Human Resource Development Review, 4(4), 373-400. doi:10.1177/1534484305281769

Brant, S. R. C. (2013). Impacto do treinamento no trabalho: o efeito mediador das estratégias de aplicação do aprendido [Training Impact at Work: The Mediating Effect of Work Application Strategies of Learning From Training]. Revista Psicologia Organizações e Trabalho, 13(3), 351362. doi: 10.1590/1678-7153.201528101

Bjork, R. A.; Dunlosky, J.; \& Kornell, N. (2013). SelfRegulated Learning: Beliefs, Techniques, and Illusions. Annu. Rev. Psychol., 64, 417-44. doi: 10.1146/annurevpsych-113011-143823

Fritsch, R., Rocha, C., \& Vitelli, R. F. (2015). Aevasão nos cursos de graduação em uma instituição de ensino superior privada [The evasion in undergraduate courses in a private institution of higher education]. Revista Educação em Questão, 52(38), 81-108. doi:10.21680/1981-1802.2015v52n38ID7963 
Iglesias, M., \& Salgado, J. F. (2012). Effectiveness of occupational training through videoconferencing: Comparison with classroom training and individual differences. Revista de Psicología del Trabajo y de las Organizaciones, 28(3), 183-188. doi:10.5093/tr2012a15

Martins, L. B., \& Zerbini, T. (2014). Escala de Estratégias de Aprendizagem: Evidências de validade em contexto universitário híbrido [Scale of Learning Strategies: Validity evidences in hybrid higher education context]. Psico-USF, 19(2), 317-328. doi:10.1590/141382712014019002007

Moraes, R. B. N. (2016). Estilos de aprendizagem em ações educacionais ofertadas a distância: Evidências de validade, validade convergente e análise conceitual [Learning styles in e-learning actions: Validity evidences, convergent validity and conceptual analysis] (Master's thesis). Retrieved from http://www.teses.usp.br/teses/disponiveis/59/59141/tde06062016-140102/pt-br.php

Oliveira, K. L., Boruchovitch, E., \& Santos, A. A. A. (2009). Estratégias de aprendizagem e desempenho acadêmico: Evidências de validade [Learning Strategies and academic performance: Validity evidences]. Psicologia: Teoria e Pesquisa, 25(4), 531-536. doi:10.1590/S010237722009000400008

Pasquali, L. (2004). Análise fatorial para pesquisadores [Factor analysis for researchers]. Petrópolis, RJ: Vozes.

Raymond, A. N., Clarke, A. D. M. \& Klein, H. J. (2014). Learning in the Twenty-First-Century Workplace. Annu. Rev. Organ. Psychol. Organ. Behav, 1, 4.1-4.31. doi: 10.1146/annurev-orgpsych-031413-091321

Salas, E., \& Cannon-Bowers, J. A. (2001). The science of training: A decade of progress. Annual Review of Psychology, 52, 471-499. doi:10.1146/annurev. psych.52.1.471

Simpson, O. (2013). O futuro da educação a distância: Que fatores afetarão como a educação a distância se desenvolverá no futuro? Revista Brasileira de Aprendizagem Aberta e a Distância, 12, 149-162. doi:10.17143/rbaad.v12i0.251

Umekawa, E. E. R., \& Zerbini, T. (2015). Evasão e persistência em ações educacionais a distância: Análise do perfil discente [Dropping out and persistence in distance education actions: Analysis of the student profile]. Revista Psicologia: Organizações e Trabalho, 15(2), 188-200. doi:10.17652/rpot/2015.2.517

Vargas, M. R. M., \& Abbad, G. S. (2006). Bases conceituais em treinamento, desenvolvimento e educação (TD\&E) [Conceptual bases in training, education and development (TD\&E)]. In J. E. Borges-Andrade, G. Abbad, L. Mourão (Orgs.), Treinamento, desenvolvimento e educação em organizações e trabalho: Fundamentos para a gestão de pessoas [Training, development and education organizations and work: Foundations for managing people] (pp. 137-158). Porto Alegre, RS: Artmed.
Vermunt, J. D. (1998). The regulation of constructive learning processes. British Journal of Education Psychology, 68(2), 149-171. doi:10.1111/j.2044-8279.1998.tb01281.x

Warr, P., \& Allan, C. (1998). Learning strategies and occupational training. In C. Cooper \& I. T. Robertson (Eds.), International Review of Industrial and Organizational Psychology (Vol., 13, pp. 83-121). Hoboken, NJ: Wiley.

Raíssa Bárbara Nunes Moraes Andrade is a Ph.D. student of the Universidade de São Paulo, Ribeirão Preto - SP, Brazil.

Thaís Zerbini is a Professor of the Universidade de São Paulo, Ribeirão Preto - SP, Brazil.

Authors' contribution:

All authors made substantial contributions to the conception and design of this study, to data analysis and interpretation, and to the manuscript revision and approval of the final version. All the authors assume public responsability for content of the manuscript.

Received: Jul. 18, 2017

1st revision: Aug. 13, 2018

Approved: Aug. 28, 2018
How to cite this article:

Andrade, R. B. N. M., \& Zerbini, T. (2019). Distance learning degrees: Possibility of evasion, styles and learning strategies. Paidéia (RibeirãoPreto), 29, e2931. doi: http://dx.doi.org/10.1590/1982-4327e2931 